\title{
AND ACTION!: REINTERPRETATION AND SIMULATION OF HISTORY THROUGH FILM IN DELILLO'S AMERICANA AND
} LIBRA

Slađana Stamenković, University of Novi Sad, Serbia, sladja_stamenkovic@live.com

10.31902/fll.26.2019.13

UDK 821.111(73)-31:791

\begin{abstract}
Linda Hutcheon claimed that the only way to access the past is to use texts and textual recordings of it. Today, we can interpret the mass media as textual evidence of the past which is at the same time an artifact and a means of rewriting history. Modern mass media seem to shape and reshape history and even our whole reality. Therefore, one can argue that history may be interpreted as what Baudrillard defined as a simulacrum. In Don DeLillo's novels, media are frequently used to give access to or retell past events. In both Americana and Libra, DeLillo introduces the film as a piece of evidence which offers insight into history. In Americana, David Bell sets to make a documentary on one Native American tribe, yet he decides to overtake the film and shoot the story of his life. In Libra, it is the media, and specifically the Zapruder film, which helps Nicholas Branch track the story of Kennedy's assassination. In both novels, history is revealed to be a simulation, but also a basis upon which our everyday reality exists.
\end{abstract}

Key words: history, simulacrum, DeLillo, Baudrillard, media.

\section{Introduction}

Owing to the popular phenomena of fake news, alternative facts and the principles of media spin that are currently being exposed in the global media, it is more interesting than ever to discuss to which extent the reality and, consequently, history are constructed and misrepresented for the audience around the world. Although we are only discussing the possibility of media manipulation today, there is little doubt that this phenomenon has not been happening for as long as there was any given form of media.

The questioning of the official history started roughly with modernism, but it is postmodernism that seems to be the prime time of skepticism to any official narrative that has long stood on a pedestal of untouchability. This is especially true for the contemporary epoch of postmodernism, however the theoreticians chose to name it. History is, today more than ever, just a story, a narrative only to a certain degree factual, with a strong potential for fictionality. 
As for literature, one of the writers that have been dealing with the issue of history and its artificial nature is the American contemporary novelist Don DeLillo. From his first novel Americana to his latest Zero $K$, DeLillo has raised the question of the realness of the grand narratives such as history. In his novels, he often borrowed an event from American history in order to try to expose the ways history may be misleading us, as he did with Kennedy's assassination in Libra. It is specifically the possibility of misleading the public through the media that connects Americana and Libra. In both cases, history is given to the reader indirectly, filtered through the lenses of a film camera. How history is represented in these films and how we see the extent to its distortion is quite in accordance with the postmodern approach to history and its fictionality.

\section{Theory of History}

Jameson begins his observations on postmodernism by noting that postmodernist fiction is basically "an alarming and pathological symptom of a society that has become incapable of dealing with time and history" (10). He begins to tackle the problem of "the disappearance of a sense of history" (Jameson 20), which is resonant of Fukuyama's writings on the end of history. Many theoreticians, like Boxall, have argued that in DeLillo's fiction there is "the loss of the grounds upon which a material history might found itself" (8). In this light, various scholars to this day interpret DeLillo's fiction as a testimony to such fatalistic theories. Yet, there are arguments to prove that the end of history is not something DeLillo considers true. His approach seems to have more with the questioning of history, than with abandoning it altogether. Boxall also mentions this second, more probable, approach in which history "continues to go on even though it can't go on, which conjures the phantasm of progress from a condition of profound stasis" (8). This approach does connect history to the notion of death, but does not claim that history itself is dead; what is dead, though, are the superimposed beliefs about history and its teaching. The new notion of history, as Boxall eventually agrees, is based on the birth of both history and America (specifically important for DeLillo's novels), not on their respective ends. He notes:

Rather, the millennial moment that is characterized as the end of history in Americana is cast as the eternally deferred moment in which the America that inhabits all of these novels might come fully into being. The novels are speeding towards the mythical moment at which Bell, DeLillo and America reach a point of religious becoming. (23)

Translated to the notion of history in theory, we can say that where Kojeve and Fukuyama see an ending, one might argue a beginning is taking place. 
What changes is the approach to history and the perception of its nature. In that fashion, Donovan claims that the "absolutist tenets we habitually rely on - scientific principles, religious systems, versions of the past we cherish as true history - are transient constructs, shifting with the times, with the moods of the populace, with the whim of chance" (1). Even Jameson admits, relying on Hegel, that the postmodern society has experienced a "characteristic turn in [its] thinking about history" (73).

Therefore, what postmodern authors do, as Boxall colorfully describes while discussing DeLillo's Libra, is that they try "to find a narrative means of delving beneath the shroud, of penetrating the sacred, mythical darkness that lies at the heart of history" (143). O'Donnell mentions Jean François Lyotard and his The Postmodern Condition: A Report on Knowledge (1979) to support the claim that "history can be no longer thought of as a grand metanarrative, but that it is composed of multiple petites histoires" (125). He goes on to recall Foucault, Hutcheon and other postmodern, post-Marxist theoreticians and historians to support this shifted view on history as something which is not God-given, an axiom that is never to be questioned. In Hutcheon's words, what takes place is more of a "skepticism rather than any real denunciation" (106). O'Donnell mentions all of the above in the context of the "new historicism" which he defines as:

[A] set of critical methodologies and practices that represent an attempt to view imaginative work as emerging within interconnected local and global circumstances that reveal the operative cultural assumptions of a given moment or epoch. (125)

Yet, there is little possibility that this postmodern approach is groundbreaking or new in any sense of the word. O'Donnell also argues that, as a genre, "the novel has always both imitated and parodied the writing of history" (124). It is a task of literature and fiction in general, one could say, to approach the official historical narratives with a grain of salt, questioning both the perspective and the facts which are presented as objectively true. What may be seen as a new feature brought about by the postmodernist theoreticians and writers is that they "viewed history not as a series of grand events, but as comprising myriad local factors observed over long periods of time" (O'Donnell 125). Thus, by putting the focus on the individual, postmodernists are able to perceive history not as the grand force of human existence, but as a collection of stories. To further enhance their approach, they stopped believing that history is a "linear strand of facts" and saw it as "mingled with other fictional narratives in the realm of the media" (Linardi 235). History, thus, became open not only for literature, but the media, as well. 
Such understanding of history provided a possibility for reinterpretation, at which point historiographic metafiction came into being. A term introduced by Linda Hutcheon, it denotes such works of fiction which are "both intensely self-reflexive and yet paradoxically also lay claim to historical events and personages" (5). This means that writers may use historical facts as a basis to their stories and from then on build fictional embellishment, adding invented events, people, places, and so on. Historiographic metafiction is mainly used to express the perception of both "history and fiction as human constructs" and to make "the grounds for its rethinking and reworking of the forms and contents of the past" (Hutcheon 5). In essence, it is this form which captures the postmodern fashion of challenging the "very separation of the literary and the historical" (Hutcheon 105). It creates "the illusion that the opposite can happen, that a historical figure can walk out of a real cafe and show up in a fictional house" (McHale 90). In doing so, historiographic metafiction provides a means to transgress "an ontological boundary between the real and the fictional" (McHale 90).

Among the great number of postmodern writers, of which DeLillo is an example, what has been identified as the main means of blurring the lines between the real and the fictional is the phenomenon of the media. Linardi points out that, in the modern society, "[h]istorical narrative and texts give way to the media narrative of images" (235). Once this happens, we can discuss the appearance of simulacra. Discussing history as a type of simulacra is especially justified once Baudrillard's America is taken into account. His interpretation of the American reality as one big screen echoes the process of simulation that he had previously written about in Simulacra and Simulation (1981). On American reality Baudrillard writes the following:

It was there before the screen was invented, but everything about the way it is today suggests it was invented with the screen in mind, that it is the refraction of a giant screen. This is not like a Platonic shadowplay, but more as if everything were carried along by, and haloed in, the gleam of the screen. Along with flux and mobility, the screen and its refraction are fundamental determinants of everyday events. (55)

If we consider the frequent occurrence of technology in DeLillo's writing, we can argue that history is indeed being simulated in all of his novels. O'Donnell defines photography as a "mechanical art that depends upon copying and reproducing an original" (127). By analogy, the same can be said of the Internet, television, film, advertising, and all of the other forms of media that appear in DeLillo's novels. Due to the dependence on the technology and the media that the American society exhibits, we can discuss the possible "disappearance of history and the real in the televisual" (Baudrillard 101). More pre- 
cisely, in Americana and Libra, we can discuss the rewriting and reconstruction of history through the process of simulation. Linardi notes that DeLillo's America is "so embedded in the media simulacrum that it is often not possible to know whether the characters are behaving according to media codes or whether they still keep some control of their lives" (234). By blurring the lines between the real and the fake, the media provides a vast soil for reconstructing, rewriting and overall manipulating past events and official history.

\section{Rewriting History in Americana and Libra}

As a true postmodernist, DeLillo treats history as a relative category and approaches it with caution. For him, "history is just a collection of narratives" (Donovan 7); narratives which may or may not be trustworthy. For this reason, in his fiction, "there is an ongoing struggle to discover the counternarrative, to angle oneself against the historical current" (Boxall 7). Of DeLillo's take on history and social circumstances, Boxall also writes that in the "development of his fiction" there is "a historical trajectory towards the millennium, and towards the globalization of US military and economic power" which reflects "a history of resistance to cultural uniformity" (5).

This particular resistance of which Boxall speaks can be spotted in the way DeLillo treats history itself, as a master narrative, a type of cultural uniformity, constructed by the media. In DeLillo's novels, it is the media and their manipulations of different events which are one of the major topics. DeLillo frequently dwells on different motifs related to the media and their correlation to the centers of power. For example, in Mao II, he focuses on propaganda; in Underworld and White Noise, his main concern is television, but other media and their effect on the audience, as well; in Cosmopolis, he examines the new media that is the Internet and its close connection to technology; and in Great Jones Street, he guides the reader through the world of celebrities and their cult propagated by the media.

When it comes to Americana and Libra, specifically, media is the main means in rewriting history, both a collective one (history and historic events of America) and more personal ones (private recollection of the past of DeLillo's characters). In order to rewrite different aspects of history, DeLillo and his characters employ two strategies. The first one is based on historiographic metafiction. The characters take one real past event and build a fictional story around it. They base their premise on the real events, but add fictional facts and background. The second strategy is based on completely rewriting history. As opposed to historiographic metafiction and its narrative, this strategy means that DeLillo's characters entirely invent past events and disregard the reality altogether. 


\section{The Media Write History}

In both of these approaches to rewriting history, DeLillo and his characters rely on the media. The examples of the media and the ways it manipulates the reality include television, advertising, magazines, and other; but the main operative weapon in the reconstruction of history is the film. In particular, in both Americana and Libra, the films in question are documentaries. In Americana, David Bell sets off to shoot a documentary about the Navaho people, yet hijacks the project in order to film an artistic attempt at a documentary about his own life. Donovan notes that film is "the key to Bell's soul, providing him a fleeting sense of control, but only by stripping content from image" (30). In Libra, Nicholas Branch uses the Zapruder film, a documentary about Kennedy's assassination, in order to reconstruct the events related to this historical moment and solve the mystery of the murder.

It is peculiar that DeLillo employs specifically documentaries as a genre to help his characters manipulate history. One may argue that DeLillo's obsession with film stems from the fact that it belongs to "technologies that promise to eradicate death" (Boxall 10). In other words, it is one of the ultimate historical artifacts which would preserve real events from destruction. Still, DeLillo does not shy away from all the possibilities that film has to offer for the purposes of manipulation. Bell does note that "the possibilities of film seemed unlimited" (Americana 33 ) and he is somewhat aware that the nature of those possibilities may be more or less sinister. Now, a film which is openly a fictional artifact (i.e. a mainstream entertainment movie) can indeed be used to affect how the general public perceives history, but it may not be the most effective means of doing so. However, a documentary could have a far more significant role in rewriting history, solely based on the fact that it commands higher authority over the truth. Documentaries are, by default, believed to "display social realities [...] directly representing the events and phenomena of an epoch" (Kellner 14). For this reason, people tend to believe what they are presented in a documentary, trusting the format to be supported by historical facts. However, as Kellner argues, they are also constructs prone to manipulation and misuse.

[D]ocumentaries may also have resonant images and characters that impress themselves deeply on audiences and change their perceptions and perhaps even behavior, as well as providing historical-contextual understanding and factual information. Yet documentaries themselves are constructs and have their biases and entertainment and fictive components. (52)

The fact that David Bell uses a documentary to tell a false story of his life might testify of his mal-intentions and thus, on a greater scale, the mal- 
intentions of people in power, who decide which documentaries get released in public. He does not intend to artistically represent his life; he aims to fool his audience into believing that his life was by far more exciting and exotic than it was. His motives are revealed even further when he openly confesses his plan to release the documentary in 30 years' time, so no one could reveal his fraud, because no one will remember it at that time (or rather, those who remember it, will long be deceased). His film is obviously scripted, the events that he narrates through his film are no truer than the rumors which circulate through the offices of his workplace, and even the people who appear in his life story are imposters - he hires actors to represent what he would like to be his life. What is more, he intends to make an "artsy" type of film, as fragmented as reports of Kennedy's assassination will be in Libra. This avoidance of telling his story straightforwardly may be another strategy which is to mask the fact that he is trying to twist the truth about his life.

I'm thinking of making a long messy autobiographical-type film [...] a long unmanageable movie full of fragments of everything that's part of my life, maybe ultimately taking two or three or more full days to screen and only a minutely small part of which I'd like to do out here. Pick out some sleepy town and shoot some film. (Americana, 96)

It can be said that David Bell represents the dominantly white power holders more than any of DeLillo's characters, because in his takeover of the documentary he not only exhibits how people of power feel they hold control over what is true, but how the white culture imposes its own perspective of the truth on the marginalized, minority cultures. It is highly symptomatic that Bell practically steals the documentary from the Navaho people, thus superimposing his own personal history over the collective history of an already oppressed culture. In doing so, he does not only indirectly shows his belief that the white perspective is more important than the Native American is - he believes his own personal, individual story is more significant than anything else.

Moreover, Americana does not identify the film as the only example of how the media distorts the perspective of reality for the general audience. David Bell is a TV executive, and the novel opens the door of the inner world of television for DeLillo's readers. We see that what the television broadcasts is not much different than Bell's scripted film, because the truth is not the value which guides the executives in creating quality programs. During their sessions at which they discuss the programmes which will eventually end on air, the reader is painfully reminded just how much profits and ratings shape the content we are being served by the media.

The fact that the truth no longer lives on television is perpetuated by Bell and his colleagues, as well. Their interpersonal relationships are shallow and 
heavily based on different rumors spread by secretaries (but other employees, too). Even the way they behave is fake and non-genuine. For example, David Bell's everyday behavior is one endless stream of imitating the famous movie stars who are his personal heroes, such as Burt Lancaster and Kirk Douglas. Much like Eric Packer (Cosmopolis) frequently asks himself how he would look on camera at any given moment, Bell asks himself what his favorite celebrities would do and how they would behave in specific situations.

Furthermore, the list of the media which participate in the false creation of the reality does not end with this. Another important person in Bell's life is his father, whose legacy in the world of marketing and advertising is often overshadowing Bell's life. The stories of his adverts might be another proof of how false information is Machiavelistically interwoven with success and the influence on the audience. If his father's adverts are not sufficient proof of how much the media is separated from reality in DeLillo's America, then one example from Bell's life should be. Namely, Bell flips the pages of a magazine and, at one point, he sees an article with the photos from the Vietnam war which depict decapitated villagers. What Bell immediately comments on is that on the very opposite page, there is an advert for women's lingerie, specifically a pantygirdle. This scene might not have the same impact if it were not for Bell's earlier comment about the war. He says that the "war was on television every night but we [people] all went to the movies" (Americana, 5).

Libra does not offer any different, more reassuring view of how the media affect one's life on the most fundamental level. Linardi argues that Oswald's behavior is "grounded on media hyperreality, insofar as his actions follow media codes of TV shows and films" (240). She supports such claims by highlighting the scenes in Libra when Oswald fails to see a difference between the real and the fictional when meeting John Wayne. He even finds comfort in the "screen laugh" being "repeated in life" (Libra, 93). This is, of course, not to depict Oswald as a character whose removal from the reality is the reason why he does all the things that he does. John Kennedy, his direct opposite, is not depicted in any better light regarding the media influence. His character is also relying on the media, as much as Oswald, because "what they cannot express through words, they convey by means of their images" (Linardi 240). The public persona of the president is also supporting these claims, as explained in the following passage:

Kennedy's life shows how reality is easily simulated in the realm of the media, and how the images displayed on TV screens do not necessarily correspond to reality. However, because television has always shown images of the world as if it were merely mirroring them, [...] what is shown on television is accepted as reality by the viewers. (Linardi 240) 
Such manipulation of the way people perceive their imminent reality corresponds to the way people perceive history. The processes are parallel insofar as it does not matter whether what is being perceived belongs to the past or the present. The point is that the facts based on real events are twisted into something different, to a smaller or greater degree. Therefore, what happens in the present enters history as a distorted image of itself, an image which is processed and filtered by the media. And what DeLillo seems to highlight is the fact that once an event or person has entered the history, there are scarce means for discovering what the real truth behind them really was. One may attempt to reconstruct the past, but can rarely assess the level of manipulation that happened beforehand.

\section{Reconstructing History}

As opposed to the creation of a documentary in Americana, Libra depicts how an already existing documentary (whether it is true or false is never discussed) affects the way people perceive past events. In Donovan's words, DeLillo here introduces "a fictional history with the stability of truth" (55) especially in the part where Lee Harvey Oswald is depicted. On a general note, in Libra, Nicholas Branch, a retired CIA agent, undertakes a task to investigate Kennedy's assassination. Branch uses the famous Zapruder film and footage of Jack Ruby shooting Lee Harvey Oswald, among other reports, to reconstruct this past event and everything related to it. What we might discuss at this point in DeLillo's works is the fact that history seems to be, in a way, always a reconstruction. What also seems to be the point which DeLillo makes in Libra is that the objective story of the past events, a story so complete that it is the ultimate truth of what had actually happened, is an elusive category which, potentially, does not even exist; i.e. it is not possible. History is always available to us in fragments, much like Kennedy's assassination is available to Branch. DeLillo describes the Zapruder film as "the basic timing device of the assassination and a major emblem of uncertainty and chaos" (Libra, 441). This particular historical evidence is, therefore, simultaneously a record of real past events and a device of confusion. Branch only gets bits and pieces which never form a quite complete puzzle, because alongside "the powerful moment of death" the footage contains "the surrounding blurs, patches and shadows" as well (Libra, 441). Moreover, the confusion does not end there, as Boxall also notes. The film might further confuse the reality by surpassing it, by leading to "certain weightlessness and timelessness, a simultaneity, an undoing of history, a cancellation even of the history of film" (Boxall 10). In that same passage, Boxall continues as follows: 
It is film, in DeLillo as in Deleuze, that offers to mark a hiatus in an exhausted culture. The Zapruder film, for example, contains, in its capturing of the Kennedy assassination, a kind of disruptive historical disjunction; in capturing the historical moment, it opens history to Deleuze's "something from the outside or from elsewhere." Even in its capacity to deliver time to us in its completion, [...] the film carries within it a kind of surplus, a death that remains at work in the grain of the celluloid. (10)

What further complicates the puzzle is the fact that these fragments are always given from a subjective point of view. Even an artifact as seemingly objective as a piece of the film, such as the Zapruder film, is shot from a subjective perspective of a nearby witness. It is just a materialized version of what the spectator saw with his own eyes, but it does not offer any further insight into the events which might reveal the truth about the murder. Moreover, whenever a subjective perspective is introduced to presenting historical facts, we can talk about historiographic metafiction. However pure Branch's intentions were, his reconstruction might as well be building a fictional narrative around the scarce evidence about an actual historical event. Yet, Branch is an epitome of a man on a mission who intends to respect history as we know it. He tries to write a history, as he notes, "not a study of the ways in which people succumb to paranoia" (Libra, 57). The language which he tries to use is clipped and dedicated to facts only. All of this, however, comes from the fact that Branch is aware that historical facts are not always the correct recordings of the past events. The following passage seems to suggest so:

And Branch wants to believe that's all it is. There is enough mystery in the facts as we know them, enough of conspiracy, coincidence, loose ends, dead ends, multiple interpretations. There is no need, he thinks, to invent the grand and masterful scheme, the plot that reaches flawlessly in a dozen directions.

Still, the cases do resonate, don't they? (Libra, 58)

This idea is reinforced in the second big story of Libra which introduces Lee Harvey Oswald and his life. DeLillo himself is now the one who employs historiographic metafiction in an attempt to breathe life into a historically intriguing, yet not sufficiently investigated personality. The reader has an opportunity to see the story behind the assassination - the motive, the profile of the shooter, the circumstances which shaped the profile of a murderer. We see Oswald as a poverty-stricken individual who is frustrated by the television and what it broadcasts. The news and propaganda from TV stations affect his thinking and directly affect the ways he sees the world. Far be it from an excuse, DeLillo's 
portrayal of Oswald does not seek to justify his acts. This depiction is just an attempt to represent the other, hidden side of the history, or at least to imagine it. The huge message that Libra sends (alongside almost every other DeLillo's novel) is that there is always a part missing, an unattainable angle from which a historical person or event may be perceived that would complete the story of objective truth. In Libra, Ferrie defines this missing spot as a "gap [which] is found between the 'parallel lines' of the plot, between Oswald and Kennedy, between time and space" (Boxall 149). This missing part, as seen in the words of Libra is "a 'third line' that 'has no history"' (Boxall 149). No history, that is, because we cannot access it. Therefore, for us, it is empty and ethereal, inexplicable and far out of the reach of the human reason.

The concept of history gains yet another important trait at this point for DeLillo. In one scene, Oswald says that "we live forever in history" (Libra, 101). Therefore, it can be argued that his need to enter history is reflective of his attempt to gain an identity or, more precisely, to build one for himself. If we accept the definition of the concept of identity as a connection "between the "inside" and the "outside" - between the personal and the public worlds" (Hall 598) then we can argue that entering history (even by undertaking some extremist actions) may be interpreted as a manner of forming an identity. Even Hegel recognized "the motor of history as a struggle for recognition" (Jameson 89). Hence, it can be said that Oswald seeks to create a public persona which would reflect for him the public opinion about himself. Based on that feedback, he could finally be able to build his own personal identity. DeLillo seems to have a similar idea, as seen from the following quote:

History means to merge. The purpose of history is to climb out of your skin. He knew what Trotsky had written, that revolution leads us out of the dark night of the isolated self. We live forever in history, outside ego and id. He wasn't sure he knew exactly what the id was but he knew it lay hidden in Hidell. (Libra, 101)

This idea seemingly corresponds with Bell's drive behind making a film about his life. He does not do it solely to deceive the audience for the fun of it; he is desperately trying to become a person he longs to be and is seeking something to prove the authenticity of his story. Through his documentary he tries to enter history, as well; or even more to leave a material trace of his personal history in the larger scope of a collective history. 


\section{What Is Real?}

The question that remains lingering in the aftermath of every example from Americana and Libra is quite simple, yet complicated: which version of history is real? How can we claim with certainty which perspective and version of past events is the right one? What is more, is it possible to claim anything with certainty in DeLillo's novels and his fictional America?

All of these bring us back to Jean Baudrillard and his dilemma: what is real? Is it possible to define the category of the real to begin with? In a very postmodern fashion, there is little hope in both Baudrillard's writings and DeLillo's novels for determining just how much of history is real and how much is fabricated. In the world whose reality is driven by the media, in a hyperreality that the contemporary world lives in, there seems to be no way to even determine which information is based on real events and which is fabricated. Yet, the question that finally follows all the above-mentioned questions is: does it really matter?

For postmodernists, history is both a story of real past events and a story based on somebody's imagination (to a bigger or lesser extent). It is this understanding of history that is the source of what both Donovan and Jameson suitably name "the postmodern freedom to toy with the past" (Donovan 6). Anything revealed as a construct is, therefore, open to subversion and reinterpretation. The goal of such experimenting with the past seems to bring us back to the previous question of what is real. DeLillo's characters, in a way, interact with history in different ways to discover some inner truth of the known events.

In every novel, DeLillo tries to answer the question of what is real. This question essentially drives each and every one of his protagonists. They all seek something real in their lives, which is why they undertake different personal quests to seek for the hidden something which would give meaning to their lives. Eric Packer searches for something that "charts", something that will help him understand life better; Bucky Wunderlick also tries to find something real in his life by escaping his public persona and returning to his solitude where his talents hide in their tortured exile; Nick Shay moves to the west and travels to Kazakhstan in order to discover himself, similarly to his brother, to mention but a few. Boxall argues the same in the following quote:

From Americana to Underworld, the novels look for a spatial and a temporal ground [...] that have not yet been colonized, for culturally specific and diverse histories that have not yet been erased. (5-6)

In Americana and Libra, David Bell and Nicholas Branch both are on the quest for the real, however hidden their motifs were. Bell's undertaking may 
seem immoral, his project is an utter fraud, but his journey to the west, his abandoning his job and people in his life and even his directing a fake story of his life can all be interpreted as his quest for answering the question of his true identity and his personal history (and the one of his family). An argument can be made that underneath his actions, Bell's urge to discover his real self is the strongest motivation he has in his life. In a similar fashion, Branch tries to find something real, only on a collective level. His quest is a quest for the truth about one of the arguably most traumatic events in the history of the American nation. Oswald is, also, on the quest for the real; it is just that what is real for him is an identity which he would create for history to remember, as many before him did. In fact, history is a way for him to become real.

Trotsky in the Bronx. But Trotsky was not his real name. Lenin's name was not really Lenin. Stalin's name was Dzhugashvili. Historic names, pen names, names of war, party names, revolutionary names. These were men who lived in isolation for long periods, lived close to death through long winters in exile or prison, feeling history in the room, waiting for the moment when it would surge through the walls, taking them with it. History was a force to these men, a presence in the room. They felt it and waited. (Libra, 34)

This passage resonates with what Boxall later wrote about the becoming of history. He states that historical figures and events "wheel into themselves, until they reach that mystical point at which they 'enter history', the point at which they assume the heavy responsibility of being what they are" (131). Yet, this becoming is soon revealed as somewhat false, solely because of the fact that it seems too scripted. Boxall points out that the "two most powerful authorial influences within the novel work in opposite directions" (134). Namely, Branch reconstructs the story by moving backwards from the aftermath of the assassination, whereas Win Everett, Laurence Parmenter, and T-Jay Mackey "work prospectively, inventing Oswald" (Boxall 134) or, in other words, scripting him into existence that the official history will advocate in which he is a "Ione gunman" (Libra, 28), a lunatic on a mission. In one direction or the other, never has the notion of identity (and, by parallel, history) been revealed as a construct as much as in this DeLillo's novel. The frightening point is that, in both cases, Oswald does not get to construct his own identity into existence, because someone else is doing that for him with the help of the media. The person himself is "caught between the frames of these two opposing plots, these narratives which meet at Zapruder frame 313" (Boxall 134). His human existence is so inconsequential that if he "hadn't existed, the CIA would have invented him" (Tate 30 ). In other words, the official history does not necessarily operate with 
actual persons, but with historical personas which may or may not be based on actual people. Differently put, history can also simulate the version of the truth the powerful find suitable.

As if this was not troubling enough, Boxall proposes the possibility of the third author (although, if we, by the order of metafiction, count in DeLillo, as well, the number rises to the scary amount of four authors per one lonely Oswald). This third author is more of an influence, but a powerful one. It is, of course - history itself. He states that:

DeLillo's fictional Oswald is shadowed, influenced, and to some extent written by the 'real' Oswald, the Oswald whose life was determined by political and historical forces which spanned the globe, which broke the back of the twentieth century, which have brought us to where we are now. (135)

Therefore, he continues, "it is possible to read this process whereby history shapes Oswald, scripts him and prepares him for his role" (142). In this light, it can be argued that "Libra performs a service to popular history by putting to rest the notion of Oswald as a lone gunman who popped out of nowhere" (Tate 30).

\section{Conclusion}

Don DeLillo has established himself as one of the finest postmodernist writers, and his approach to history may be one of the reasons for achieving the status he today enjoys. In his novels, history is not denied or thrown away. However, it is approached carefully, as a possible simulacrum, a matter potentially tarnished by dark forces of manipulation for power. As in Hutcheon's writings, one can see in DeLillo's works the contradictory nature of postmodernism, "one that is heavily implicated in that which it seeks to contest" (106). His characters prove history wrong and ill-intentioned, while at the same time depending on it for the purpose of their own identity. What the reader is ultimately left with is an "unresolved contradiction" (Hutcheon 106) and a task to decide for himself which side to go along with.

It may be America that DeLillo writes about, but the issues which arise in his novels are symptomatic of the entire global society. In America, Baudrillard writes that Americans "are people of conviction, convinced of everything and seeking to convince" and "to reconstitute everything of a past and a history which were not their own and which they have largely destroyed or spirited away" (41). Yet, nowadays, there seem to be no boundaries between the states, countries or continents when it comes to the reinterpretation of both history 
and reality. DeLillo's America which levitates among the floating media images of both everyday and history is a metaphor for the entire contemporary civilization. One may see in this a pessimistic, even fatal promise of the future, but to some extent, the approach toward reality and history that DeLillo's characters share might be liberating, at the same time. By questioning the official history, which by now we know is simulated at least to some degree, we allow the individual histories to end their silence and offer an insight into reality from a different perspective. And it is precisely this that seems to be the greatest victory of postmodernism.

\section{Works Cited:}

Baudrillard, J. and Dyer, G. 2010. America. London: Verso.

Boxall, P. 2012. Don DeLillo: The Possibility of Fiction. London: Routledge.

DeLillo, D. 2013. Americana. London: Penguin Books.

DeLillo, D. 2018. Libra. London: Penguin Books.

Donovan, C. 2009. Postmodern Counternarratives: Irony and Audience in the Novels of Paul Auster, Don Delillo, Charles Johnson, and Tim O'Brien. London: Routledge.

Hall, S. 1996. "The Question of Cultural Identity." Modernity: An Introduction to Modern Sciences. Eds. S. Hall, and D. Held. 596-632. Oxford: Blackwell.

Hutcheon, L. 2010. A Poetics of Postmodernism: History, Theory, Fiction. Routledge.

Jameson, F. 2009. The Cultural Turn: Selected Writings on the Postmodern, 1983-1998. London: Verso.

Kellner, D. 2010. Cinema Wars: Hollywood Film and Politics in the Bush-Cheney Era. West Sussex: Wiley-Blackwell.

Linardi, S. M. 2001. "All the World is a Screen: The Power of Media Simulacra in the Novels of Don DeLillo." Em Tese 6, 233-243.

McHale, B. 2003. Postmodernist Fiction. London: Routledge.

O'Donnell, P. 2011. The American Novel Now: Reading Contemporary American Fiction since 1980. West Sussex: Wiley-Blackwell.

Tate, G. 2003. "White Magic: Don DeLillo's Intelligence Networks." Don DeLillo. Ed. Harold Bloom, Broomall: Chelsea House. 29-32. 


\section{AKCIJA!: REINTERPRETACIJA I SIMULACIJA ISTORIJE KROZ FILM U AMERIKANI I VAGI DONA DELILA}

Linda Hačeon tvrdi da je jedini način da se pristupi prošlosti kroz tekstualne zapise. Danas je moguće interpretirati masovne medije kao tekstualno svedočenje o prošlosti koje je u isto vreme i artefakt i sredstvo prekrajanja istorije. Moderni masovni mediji, čini se, oblikuju i preinačuju istoriju, pa čak i čitavu stvarnost koju živimo. Stoga, možemo govoriti o interpretaciji istorije kao Bodrijarovog simulakruma. U romanima Dona DeLila, mediji se često koriste kako bi se pristupilo prošlim događajima. U Amerikani i Vagi, DeLilo koristi film kao dokaz koji bi nam mogao reći nešto više o istoriji. U Amerikani, Dejvid Bel snima dokumentarac o plemenu američkih starosedelaca, sve dok ne odluči da taj film preuzme i snimi priču o sopstvenom životu. U Vagi, mediji, a naročito Zapruderov film, pomažu Nikolasu Branču da istraži priču o Kenedijevom ubistvu. U oba romana se istorija pokazuje kao simulirana, mada je u isto vreme ona oslonac na kojoj počivaju čitava moderna stvarnost i svakodnevica.

Ključne reči: istorija, simulakrum, DeLilo, Bodrijar, mediji. 